\title{
Sip New Disease Reports \\ First report of bacterial black stripe on banana caused by Rhizobium paknamense in China
}

\author{
S.L. Huang ${ }^{1}$, M.L. Long ${ }^{2}$, C. Ayra-Pardo ${ }^{1}$, Z.L. Cen ${ }^{3}$, G. Fu ${ }^{3}$, L.P. Qin ${ }^{3}$, S.H. Lin ${ }^{3}$, W.H. Yan ${ }^{3}$, C.J. Hu ${ }^{3}$ and Q.Q. Li ${ }^{2}$ \\ ${ }^{1}$ School of Agricultural Engineering, Nanyang Normal University, 473061 Nanyang, China ; ${ }^{2}$ College of Agriculture, \\ Guangxi University, 530004, Nanning, China ; ${ }^{3}$ Guangxi Academy of Agricultural Sciences, 530007, Nanning, China
}

*E-mail: silianghuang@aliyun.com

Received: 17 Apr 2020. Published: 14 May 2020. Keywords: bacterial plant disease, Musa nana, Nanning

On 22 Aug 2003, an unknown disease was found on banana (Musa nana) leaves in the Guangxi Agro-Reclamation State-owned Jinguang Farm $\left(22^{\circ} 48^{\prime} 37^{\prime \prime} \mathrm{N}, 107^{\circ} 58^{\prime} 51^{\prime \prime} \mathrm{E}\right)$, Nanning, China. The disease occurred only on the rainy days during summer, with foliar disease incidence ranging from $49-81 \%(\mathrm{n}=400)$, and more than $90 \%$ of plants infected. It first appeared as water-soaked spots on the underside of affected leaves which turned into black to blackish-brown lesions. The spots enlarged faster in the longitudinal direction than in the transverse direction (Fig.1). Chlorosis occurred in the tissues surrounding the lesions. Microscopic examination detected bacterial ooze exuding from the cut surface of the lesion.

Diseased tissue pieces $\left(3 \mathrm{~mm}^{2}\right)$ were dipped in $75 \%$ ethanol for $2 \mathrm{sec}, 1 \%$ mercuric chloride for $2 \mathrm{~min}$, followed by a triple rinse with sterile water. Surface-disinfected tissue pieces were triturated in sterile water $(0.3 \mathrm{ml}$ water per tissue piece) with a glass rod to create bacterial suspensions that were spread on peptone-beef agar (NA) to obtain single colonies. One isolate (As-1) was randomly selected and identified using bacteriological and molecular methods. As-1 produced translucent and glutinous colonies on NA (Fig. 2), and was identified as a Gram-negative rod-shaped bacterium, with peritrichous flagella (Fig. 3). Fifteen positive (oxidase, catalase, phenylalanine deaminase, esculin hydrolysis, D-glucose and acetic acid oxidation, nitrate reduction, nitrate and nitrite gas production, growth on $2 \% \mathrm{NaCl}$ and $\mathrm{N}$-free media, alkaline substance production in Litmus milk, urea and sodium citrate utilisation) and 11 negative (Tween 80, methyl red and V-P tests, starch and cellulose hydrolysis, hydrogen sulphide, gelatin liquefaction, potassium cyanide, 3-ketolactose, acetamide and tartrate) reactions were confirmed. Growth temperature and $\mathrm{pH}$ ranges of As-1 were $13-43^{\circ} \mathrm{C}$ (optimum $31^{\circ} \mathrm{C}$ ) and 5.0-10.0 (optimum 6.5), respectively. The $16 \mathrm{~S}$ rDNA of As-1 was amplified and sequenced (GenBank Accession No. DQ419569). A 16S rDNA-based phylogenetic tree showed that As-1 clustered with the Rhizobium paknamense type strain L6-8T and was clearly separated from other Allorhizobium/Rhizobium spp. (Fig. 4). R. paknamense L6-8T was first reported as an endophyte of lesser duckweed (Kittiwongwattana \& Thawai, 2013), and later proposed to be reclassified as Allorhizobium paknamense (Mousavi et al., 2015). BLAST analysis showed $99.43 \%$ identity between As-1 and L6-8T.

The As- 1 isolate was grown on NA at $28^{\circ} \mathrm{C}$ for $48 \mathrm{~h}$. Colonies were suspended in sterile water to prepare a bacterial suspension $\left(1.6 \times 10^{9}\right.$ $\mathrm{cfu} / \mathrm{ml}$ ). Healthy banana leaves were gently brushed with a sterilised toothbrush to create slight wounds on their epidermis. The bacterial suspension was inoculated on the wounds with a sterilised paintbrush and incubated for four days. Black stripe symptoms occurred on the As-1-inoculated leaves, not on the control treated with sterile water. Bacterial cultures with similar phenotypes as the inocula were constantly reisolated from As-1-treated leaves, verifying that As-1 was responsible for the disease based on Koch's postulates.

Previous reports showed Erwinia, Ralstonia, Xanthomonas bacteria as the pathogenic agents responsible for different banana diseases (Blomme et al., 2017). This report is the first of $R$. paknamense causing black stripe on banana.

\section{References}

1. Blomme G, Dita M, Jacobsen KS, Vicente LP, Molina A, Ocimati W, Poussier S, Prior P, 2017. Bacterial diseases of bananas and enset: Current state of knowledge and integrated approaches toward sustainable management. Frontiers in Plant Sciences 8, 1-25. http://dx.doi.org/10.3389/fpls.2017.01290

2. Kittiwongwattana $\mathrm{C}$, Thawai $\mathrm{C}, 2013$. Rhizobium paknamense sp. nov., isolated from lesser duckweeds (Lemna aequinoctialis). International Journal of Systemic and Evolutionary Microbiology 63, 3823-3828. http://dx.doi.org/10.1099/ijs.0.051888-0

3. Mousavi SA, Willems A, Nesme X, de Lajudie P, Lindström K, 2015. Revised phylogeny of Rhizobiaceae: Proposal of delineation of Pararhizobium gen. nov., and 13 new species combinations. Systemic and Applied Microbiology 38, 84-90. http://dx.doi.org/10.1016/j.syapm.2014.12.003

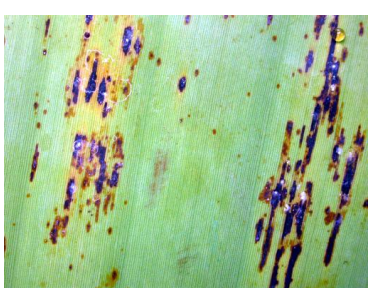

Figure 1

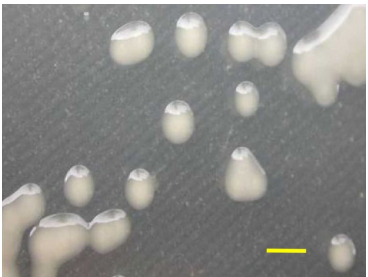

Figure 2



Figure 3

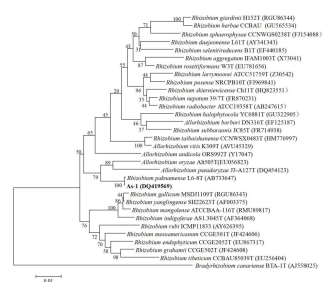

Figure 4

To cite this report: Huang SL, Long ML, Ayra-Pardo C, Cen ZL, Fu G, Qin LP, Lin SH, Yan WH, Hu CJ, Li QQ, 2020. First report of bacterial black stripe on banana caused by Rhizobium paknamense in China. New Disease Reports 41, 28. http://dx.doi.org/10.5197/j.2044-0588.2020.041.028 